\title{
ALS-Resistant Smallflower Umbrella Sedge (Cyperus difformis) in Arkansas Rice: Physiological and Molecular Basis of Resistance
}

\author{
Parsa Tehranchian, Dilpreet S. Riar, Jason K. Norsworthy, Vijay Nandula, Scott McElroy, Shu Chen, \\ and Robert C. Scott*
}

\begin{abstract}
Smallflower umbrella sedge is a problematic weed in direct-seeded rice in the midsouthern United States. It recently has evolved resistance to the acetolactate synthase (ALS) -inhibiting herbicide halosulfuron in Arkansas rice. Studies were conducted (1) to determine if the resistant biotype is cross resistant to other ALS-inhibiting herbicides, (2) to evaluate alternative herbicide control options, and (3) to determine the mechanism of resistance. Whole-plant bioassay revealed that halosulfuronresistant plants were not controlled by bispyribac-sodium, imazamox, and penoxsulam at the labeled field rate of each herbicide. The level of resistance to these herbicides, based on the lethal dose needed to kill $50 \%$ of plants $\left(\mathrm{LD}_{50}\right)$ was $\geq 15$-fold compared to a susceptible biotype. Both biotypes were controlled $>96 \%$ with bentazon and propanil and $\leq 23 \%$ with quinclorac, thiobencarb, and 2,4-D. Hence, effective control measures exist; albeit, the number of herbicide options appear limited. Based on in vitro ALS enzyme assays, altered target site is the mechanism of resistance to halosulfuron and imazamox. Massively parallel sequencing with the use of the Illumina HiSeq detected an amino acid substitution of Pro $_{197}$-to-His in the resistant biotype that is consistent with ALS-inhibiting herbicide resistance in other weed species.
\end{abstract}

Nomenclature: Bispyribace-sodium; halosulfuron; imazamox; imazethapyr; penoxsulam; smallflower umbrella sedge, Cyperus difformis L.; rice, Oryza sativa L.

Key words: ALS enzyme assay, ALS gene sequencing, herbicide resistance mechanism, Illumina HiSeq, whole-plant bioassay.

Herbicide-resistant weed evolution is more common for acetolactate synthase (ALS) -inhibiting herbicides compared to herbicides of all other groups. Worldwide, 145 weed species have evolved resistance to ALS-inhibiting herbicides, and 27 of those weed species exist in rice production systems. Rice weeds that have evolved resistance to ALSinhibiting herbicides in the United States are red rice (Oryza sativa L.), barnyardgrass [Echinochloa crusgalli (L.) Beauv.], California arrowhead (Sagittaria montevidensis Cham. \& Schlecht.), eared redstem (Ammania auriculata Willd.), late watergrass [Echinochloa oryzicola (Vasinger) Vasinger], redstem (Ammania coccinea Rottb.), ricefield bulrush [Scirpus

\footnotetext{
DOI: $10.1614 /$ WS-D-14-00147.1

* First, second, and third authors: Postdoctoral Research Associate, Former Postdoctoral Research Associate, and Professor, Department of Crop, Soil, and Environmental Sciences, University of Arkansas, 1366 West Altheimer Drive, Fayetteville, AR 72704; fourth author: Research Plant Physiologist, Crop Production Systems Research Unit, United States Department of Agriculture, Agricultural Research Services, 141 Experiment Station Road, P.O. Box 350, Stoneville, MS 38776; fifth and sixth authors: Professor and Graduate Research Assistant, Department of Crop, Soil, and Environmental Sciences, Auburn University, 201 Funchess Hall, Auburn, AL 36849; seventh author: Professor, Department of Crop, Soil, and Environmental Sciences, University of Arkansas, Box 357, Lonoke, AR 72086. Corresponding author’s E-mail: ptehranc@uark.edu
}

mucronatus (L.) Palla], rice flatsedge (Cyperus iria L.), and smallflower umbrella sedge (Heap 2014).

Nearly half of the rice in the United States is grown in Arkansas. In Arkansas, barnyardgrass, red rice, and sedges (Cyperus spp.), including rice flatsedge, smallflower umbrella sedge, and yellow nutsedge (Cyperus esculentus L.) are the main monocot weeds. Selection for ALS resistance in rice fields has been tremendous over the past $10 \mathrm{yr}$ as a result of the rapid adoption of imidazolinone (IMI) -resistant rice in the midsouthern United States, partially as a strategy to combat barnyardgrass resistance to multiple herbicides, including propanil (Baltazar and Smith 1994), quinclorac (Lovelace 2003), and clomazone (Norsworthy et al. 2009). Similar to observations with other herbicides that were widely used in rice, overreliance on IMI herbicides such as imazethapyr and imazamox in IMI-resistant rice quickly led to evolution of further barnyardgrass resistance to these herbicides (Wilson et al. 2009). Additional studies revealed that these resistant barnyardgrass biotypes had variable levels of cross-resistance to additional ALS-inhibiting herbicides belonging to the triazolopyrimidine (TP, penoxsulam) and pyrimidinyl-benzoate (PB, bispyribac-sodium) chemical families (Riar et al. 2012, 2013). 
Sulfonylurea (SU) herbicides such as bensulfuron, halosulfuron, orthosulfamuron, and thifensulfuron do not control barnyardgrass and red rice, but are the main components of broadleaf and sedge weed control programs in midsouthern U.S. rice (Scott et al. 2013). In 2010, halosulfuron failed to control a smallflower umbrella sedge population collected from a rice field in southern Arkansas. Greenhouse studies conducted at the University of Arkansas in Fayetteville revealed that smallflower umbrella sedge had evolved resistance to halosulfuron (Norsworthy et al. 2013b). Smallflower umbrella sedge has already evolved resistance to ALS-inhibiting herbicides in California (Osuna et al. 2002), Australia (Graham et al. 1996), Italy (Vidotto et al. 2003), Brazil and Spain (Galon et al. 2008; Ruiz-Santaella et al. 2004), South Korea (Kuk et al. 2004), and Turkey (Heap 2014).

Mutations in the conserved region of the ALS gene and enhanced herbicide metabolism are widely reported as mechanisms of ALS-inhibiting herbicide resistance in weed species (reviewed by Powles and Yu 2010; Siminszky et al. 2006; Tranel and Wright 2002). Several studies focused at determining the mechanism of resistance in ALS-resistant smallflower umbrella sedge conducted ALS enzyme assays that indicated an altered target site was the likely resistance mechanism (Kuk et al. 2004; Osuna et al. 2002).

Currently, sedges are not among the top five most problematic weeds of rice in Arkansas (Norsworthy et al. 2013a) because ALS-inhibiting herbicides and propanil provide good control of sedges (Scott et al. 2013). However, limited control options after widespread evolution of resistance to ALS-inhibiting herbicides may lead to greater prominence of sedges in rice production systems in this region. Consequently, experiments were conducted with objectives: (1) to confirm and characterize cross resistance to halosulfuron, bispyribac-sodium, imazamox, imazethapyr, and penoxsulam; (2) to evaluate alternative herbicides for the control; and (3) to determine the resistance mechanism in the halosulfuron-resistant smallflower umbrella sedge biotype.

\section{Materials and Methods}

Plant Material and Growth Conditions. Seeds of the halosulfuron-resistant smallflower umbrella sedge (R) were collected from a rice field in southeast Arkansas. Seeds of a known ALSsusceptible $(S)$ biotype were provided from a seed repository in Davis, CA. To confirm ALS-inhibiting herbicide resistance, seeds were sown in a 55.5 by 26.5 by $5.5-\mathrm{cm}^{3}$ plastic tray containing nonsterile potting mix (professional growing mix, LC1 Mix, Sun Gro Horticulture Distribution Inc., Bellevue, WA 98008) at the University of Arkansas greenhouse facility in Fayetteville, AK, under 30/20 \pm 3 $\mathrm{C}$ day/night temperature and $16-\mathrm{h}$ photoperiod. Seedlings at three- to four-leaf stage were treated

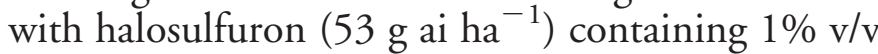
crop oil concentrate. Spray solution was applied with the use of a research track sprayer fitted with a boom containing two flat-fan 800067 nozzles (Teejet ${ }^{\circledR}$ Technologies, Springfield, IL) calibrated to deliver $187 \mathrm{~L} \mathrm{ha}^{-1}$ at $276 \mathrm{kPa}$. Five survivors were covered with net bags, self-pollinated, and seeds were collected and sown for the second generation. F1 seedlings were transplanted at the two- to three-leaf stage into plastic pots $(88-\mathrm{mm}$ height by $100-\mathrm{mm}$ diam) and used for the following studies. Pots were watered daily and once weekly with a water-soluble fertilizer (Miracle-Gro ${ }^{\circledR}$ Water Soluble All Purpose Plant Food, Scotts Miracle-Gro Products, Inc., Marysville, OH 43040).

Whole-Plant Bioassays. Dose-Response Studies. ALS-resistant and susceptible tuberlings were transplanted individually at two- to three-leaf stage as mentioned earlier. Sprayer setup and growth conditions were the same as above. Both biotypes were treated at three- to four-leaf stage with a range of rates of halosulfuron, bispyribac-sodium, imazamox, and penoxsulam. There were 20 replicates for each treatment. The herbicide rates for the susceptible biotype were $0,1 / 64,1 / 32,1 / 16,1 / 8,1 / 4$, $1 / 2,1$, and 2 times the labeled field rate of halosulfuron, bispyribac-sodium, imazamox, and penoxsulam (Table 1). Additionally, imazamox was applied at 4 and 8 times the labeled field rate because of its lower efficacy. Rates of all tested herbicides for the resistant biotype were $0,1 / 2,1,2$, 4, 8, 16, and 32 times the labeled rate. All treatments contained adjuvants (Table 1). Treatment effect with regard to plant mortality and percent dry weight reduction was recorded at 21 DAT for all herbicide treatments.

As a result of no differences between runs, mortality data were pooled. Mortality data were subjected to probit analysis with the use of PROC PROBIT in SAS to determine the lethal dose needed to kill $50 \%\left(\mathrm{LD}_{50}\right)$ of the treated plants of each biotype. Additionally, herbicide dose needed to reduce growth by $50 \%\left(\mathrm{GR}_{50}\right)$ was calculated with 
Table 1. Information about the herbicides used in acetolactate synthase (ALS)-inhibiting herbicide cross-resistance confirmation and characterization or alternative herbicide control studies. ${ }^{\text {a }}$

\begin{tabular}{|c|c|c|c|c|}
\hline Common name & Trade name & Labeled field rate & Adjuvant & Manufacturer \\
\hline & & $\mathrm{g}$ ai ha ${ }^{-1}$ & $\% \mathrm{v} / \mathrm{v}$ & \\
\hline \multicolumn{5}{|c|}{ ALS-inhibiting herbicides } \\
\hline Bispyribac-sodium & Regiment & 35 & $2.5 \%^{\mathrm{b}}$ & Valent U.S.A. Corp. \\
\hline Halosulfuron & Permit & 53 & $0.25 \%$ NIS & Gowan Company \\
\hline Imazamox & Beyond & 35 & $0.25 \%$ NIS & BASF Corp. \\
\hline Imazethapyr & Newpath & 70 & $0.25 \%$ NIS & BASF Corp. \\
\hline Penoxsulam & Grasp & 49 & $1 \% \mathrm{COC}$ & Dow AgroSciences \\
\hline \multicolumn{5}{|c|}{ Alternative rice herbicides } \\
\hline Bentazon & Basagran & 840 & $0.25 \%$ NIS & Winfield Solutions \\
\hline Propanil & Riceshot & 4,480 & - & RiceCo \\
\hline Quinclorac & Facet & 560 & $0.25 \%$ NIS & BASF Corp. \\
\hline Thiobencarb & Bolero & 4,480 & $0.25 \%$ NIS & Valent U.S.A. Corp. \\
\hline $2,4-\mathrm{D}$ & Weedar 64 & 1,065 & $0.25 \%$ NIS & Nufarm Agricultural Products \\
\hline
\end{tabular}

a Abbreviations: NIS, nonionic surfactant; COC, crop oil concentrate.

b Dyne-A-Pak: blend of nonionic spray adjuvant and deposition aid.

the use of a four-parameter log logistic function as given in Equation 1:

$$
y=c+\left\{d-c / 1+\exp \left[b\left(\log x-\log \mathrm{GR}_{50}\right)\right]\right\},
$$

where $y$ is the percent dry weight in response to herbicide concentration $(x), d$ is the upper asymptote, $c$ is the lower limit, and $b$ is the relative slope around $\mathrm{GR}_{50}$. The values of $c$ and $d$ were fixed at 0 and 100 , respectively.

\section{ALS-Inhibiting Herbicide Cross Resistance and Alter-} native Herbicide Studies. Two experiments were conducted in a randomized complete block factorial design with two biotypes and five herbicides (i.e., five ALS-inhibiting herbicides and five alternative rice herbicides) treatments with four replications. Both experiments were repeated. Smallflower umbrella sedge biotypes (four plants per replicate) at the three- to four-leaf stage were treated with field application rates of herbicides listed in Table 1. Required adjuvants were added to all treatments according to the manufacturer's recommendation (Table 1). Herbicide application procedures and growth conditions were the same as for the dose-response trials. Control was visually estimated $21 \mathrm{~d}$ after treatment (DAT) on a scale of 0 (no control) to 100 (dead plant). Aboveground biomass of all plants including the nontreated control was measured by weighing the oven-dried shoots after drying at $60 \mathrm{C}$ for $3 \mathrm{~d}$. The dry weight of each plant was converted to a percentage relative to the nontreated control for each biotype.
Control and biomass data were subjected to ANOVA with the use of PROC MIXED in SAS (Version 9.3., SAS Institute Inc., Cary, NC). The two runs were pooled and means separated with the use of Fisher's protected LSD at $\alpha=0.05$. Comparisons were made between resistant and susceptible biotypes within each herbicide and among herbicides within a biotype.

ALS In Vitro Inhibition Assay. Resistant and susceptible plants were grown as in the crossresistance study. Three to four grams of fresh leaves from plants at the three- to four-leaf stage were ground under liquid nitrogen with the use of mortar and pestle and the ALS enzyme activity assayed according to Nandula and Messersmith (2000). Technical-grade halosulfuron and imazamox provided by commercial manufacturers (Table 1 ) were used at $0,0.0001,0.001,0.01,0.1,1,10,100$, and $1,000 \mu \mathrm{M}$ concentrations for the in vitro ALS assays. ALS enzyme activity was measured, in terms of the optical density of a colored complex (based on acetoin formed from acid decarboxylation of acetolactate) at $525 \mathrm{~nm}$ against a no-enzyme blank, and expressed as percentage of control (no herbicide). Experiments were conducted in a complete randomized factorial design with two biotypes and two herbicides with three replications per treatment. Each replication represents an independent enzyme/ protein extraction from a leaf sample. The experiments were conducted three times. ANOVA was conducted on all data with the use of PROC GLM in SAS. No significant experiment effect in repeated runs was observed; therefore, data from three runs were pooled. Nonlinear regression analysis was 
applied to define a three-parametric power equation of the form

$$
y=y 0+a^{-b x}
$$

to relate the effect of herbicide concentration $(x)$ on ALS activity $(y)$, where $y 0$ is an asymptote, $a$ is a constant, and $b$ is the slope of the curve. Equation parameters were computed with the use of SigmaPlot (version 12.5, Systat Software Inc., San Jose, CA, USA).

\section{ALS Gene Assembly, Mapping, and Amino Acid} Substitution Detection. Illumina HiSeq (Illumina, San Diego, CA, http://www.illumina.com/) platform was used for massively parallel sequencing. The methodology for transcriptome assembly and nucleotide polymorphism detection in species without a sequenced genome used in the current study was suggested by Bräutigam and Gowik (2010). RNA was extracted with the use of RNeasy Plant Mini Kit, Qiagen. RNA integrity check, preparation steps, and Illumina sequencing was conducted at the HudsonAlpha Institute for Biotechnology (Huntsville, AL; http://gsl.hudsonalpha. org/). The paired-end reads were assembled into contigs with the use of the Trinity de novo assembler (trinityrnaseq_r20140413p1) (Haas et al. 2013; http://trinityrnaseq.sourceforge.net/).

A local BLAST (Basic Local Alignment Search Tool) database was established based on the assembly. Full-length ALS mRNA sequences of Schoenoplectiella wallichii (NCBI accession: AB492863) was downloaded from NCBI and searched against the BLAST database. The construction of local BLAST database and $\mathrm{tBLAST}$ x search were conducted with the BLAST suite ncbi-blast-2.2.29+ (ftp://ftp.ncbi. nlm.nih.gov/blast/executables/blast+/2.2.29/). The putative ALS contigs of each biotype were aligned with the use of Clustal Omega (http://www.ebi.ac. uk/Tools/msa/clustalo/) (McWilliam et al. 2013) and translated into amino acid sequences in CLC Genomic Workbench. The chloroplast transit peptides were predicted from the translated amino acid sequences on ChloroP 1.1 Server (http://www.cbs. dtu.dk/services/ChloroP/).

\section{Results and Discussion}

Whole-Plant Bioassays. Dose-Response Studies. The resistant biotype exhibited resistance to ALSinhibiting herbicides of four chemical families based on dose-response curves relative to a susceptible biotype (Table 3 ). The R/S ratio calculated from
$\mathrm{LD}_{50}$ values revealed that the resistant biotype was $>69,>95,>15$, and 27 -fold less sensitive to bispyribac-sodium, halosulfuron, imazamox, and penoxsulam, respectively, compared to the susceptible biotype. Similarly, the $\mathrm{GR}_{50}$ values of bispyribac-sodium, halosulfuron, imazamox, and penoxsulam also confirmed resistance similar to that observed for the $\mathrm{LD}_{50}$ values (Table 3). Based on the ratio of $\mathrm{GR}_{50}$ values, the resistant biotype was $\geq 12$-fold less sensitive than the susceptible biotype to all herbicides tested.

Various levels of herbicide resistance have been reported for many weed species that have evolved resistance to ALS-inhibiting herbicides. According to Osuna et al. (2002), smallflower umbrella sedge plants from California were $>10$ and $>26$ times less responsive to bispyribac-sodium and bensulfuron, respectively, than a susceptible biotype. Smallflower umbrella sedge from South Korea demonstrated a 2.3- and 1,073-fold level of resistance to bispyribac-sodium and bensulfuron, respectively (Kuk et al. 2004).

ALS-Inhibiting Herbicide Cross-Resistance. Control of the susceptible biotype with all tested ALSinhibiting herbicides was $\geq 90 \%$ (Table 2). In contrast, the resistant biotype was controlled only 6 to $49 \%$ with these herbicides. Trends for the biomass data were similar to visual control data, and thus, only visual control data were presented. Crossresistance to ALS-inhibiting herbicides has been reported previously in smallflower umbrella sedge biotypes. For instance, biotypes from Italy and California had variable levels of cross resistance to SU, IMI, TP, PB, and sulfonylamino-carbonyltriazolinone (SCT) herbicides (Merotto et al. 2009), whereas a biotype from Spain was resistant to the SU herbicides bensulfuron and halosulfuron, but not to IMI and PB herbicides (Busi et al. 2006).

Alternative Herbicide Control. Bentazon and propanil controlled the resistant and susceptible biotypes $\geq 96 \%$ (Table 2). In contrast, control of both biotypes with quinclorac, thiobencarb, and 2,4-D was $\leq 23 \%$. Among the herbicides labeled for use in Arkansas rice, bentazon and propanil are two of the most effective options for control of ALSresistant smallflower umbrella sedge (Norsworthy et al. 2013b). Similarly in Brazil, an application of bentazon at the labeled field rate provided complete control of ALS-resistant smallflower umbrella sedge (Galon et al. 2008). 
Table 2. Visual control (0-100\%) of halosulfuron-resistant and -susceptible smallflower umbrella sedge with acetolactate synthase (ALS)-inhibiting herbicides and alternative rice herbicide options at $21 \mathrm{~d}$ after treatment.

\begin{tabular}{|c|c|c|c|c|}
\hline \multirow[b]{2}{*}{ Herbicide } & \multirow[b]{2}{*}{ Rate } & \multicolumn{3}{|c|}{ Control } \\
\hline & & Susc & eptible & Resistant \\
\hline & $\mathrm{g}$ ai ha ${ }^{-1}$ & & {[} & 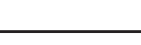 \\
\hline \multicolumn{5}{|l|}{ ALS inhibitors } \\
\hline Bispyribac-sodium & 35 & 95 & $\mathrm{~A} \mathrm{~b}^{\mathrm{a}}$ & $6 \mathrm{~B} \mathrm{c}$ \\
\hline Halosulfuron & 53 & 100 & A a & $24 \mathrm{~B} \mathrm{~b}$ \\
\hline Imazamox & 35 & 90 & A c & $6 \mathrm{~B} \mathrm{C}$ \\
\hline Imazethapyr & 70 & 96 & $\mathrm{~A} \mathrm{~b}$ & $7 \mathrm{~B} \mathrm{c}$ \\
\hline Penoxsulam & 49 & 98 & $\mathrm{~A} a b$ & $49 \mathrm{~B} \mathrm{a}$ \\
\hline \multicolumn{5}{|c|}{ Alternative rice herbicides } \\
\hline Bentazon & 840 & 98 & A a & $96 \mathrm{~A} \mathrm{~b}$ \\
\hline Propanil & 4,480 & 100 & A a & $100 \mathrm{~A} \mathrm{a}$ \\
\hline Quinclorac & 560 & 13 & A c & $17 \mathrm{~A} \mathrm{c}$ \\
\hline Thiobencarb & 4,480 & 23 & $\mathrm{Ab}$ & $4 \mathrm{Ad}$ \\
\hline $2,4-\mathrm{D}$ & 1,065 & 21 & $\mathrm{~A} \mathrm{~b}$ & $18 \mathrm{~A} \mathrm{c}$ \\
\hline
\end{tabular}

${ }^{\text {a }}$ Means for each herbicide within a row followed by the same uppercase letters and mean for each biotype within a column followed by the same lowercase letters are not significantly different according to Fisher's protected LSD test $(\alpha=0.05)$.

Nevertheless, prudent use of propanil is needed, as an ALS-resistant smallflower umbrella sedge population has already evolved resistance to propanil in California (Pedroso et al. 2013).

ALS In Vitro Inhibition Assay. Halosulfuron and imazamox required for ALS I 50 (herbicide concentration required to inhibit enzyme activity by $50 \%$ ) was 660 and $40,500 \mu \mathrm{M}$, respectively, for the resistant biotype and 53 and $43 \mu \mathrm{M}$, respectively, for the susceptible biotype (Table 4). Based on the ratio of resistant to susceptible $\mathrm{I}_{50}$, ALS of the resistant biotype was 13-fold less sensitive to halosulfuron and 942-fold less sensitive to imazamox than ALS of the susceptible biotype, suggesting an altered target site as the mechanism of resistance. ALS enzyme activity-based resistance has previously been reported in smallflower umbrella sedge biotypes from Italy and California (Merotto et al. 2009). Low level of resistance to halosulfuron, despite high whole-plant level resistance, may indicate involvement of other mechanisms of resistance, such as target-site amplification and differential absorption, translocation, and/or metabolism. ALS gene amplification has not been reported to date in any weed species resistant to ALS-inhibiting herbicides. We have not been able to obtain ${ }^{14} \mathrm{C}$-halosulfuron to carry out absorption/ translocation/metabolism studies, in spite of exhaustive search for vendors. A Pro $_{197}$-to-His substitution (see below) does not explain the low ALS-based halosulfuron resistance nor the high level of imazamox resistance. Other species in which the Pro $_{197}$-to-His mutation has been documented exhibit susceptibility to moderate resistance to IMI and high levels of resistance to SU herbicides (Tranel et al. 2014). The ALS enzyme response to these herbicides should be further investigated for posttranslational modifications such as phosphorylation/de-phosphorylation with the use of a purified enzyme extract with high specific activity.

Table 3. Level of resistance to bispyribac-sodium, halosulfuron, imazamox, and penoxsulam in acetolactate synthase-resistant smallflower umbrella sedge. ${ }^{\text {a,b,c }}$

\begin{tabular}{|c|c|c|c|c|c|c|c|}
\hline Herbicide & Biotype & \multicolumn{2}{|c|}{$\mathrm{LD}_{50}$} & $\mathrm{LD}_{50}(\mathrm{R} / \mathrm{S})$ & & $\mathrm{GR}_{50}$ & $\begin{array}{l}\mathrm{GR}_{50} \\
(\mathrm{R} / \mathrm{S})\end{array}$ \\
\hline & & \multicolumn{2}{|c|}{ g ai ha ${ }^{-1}$} & & \multicolumn{2}{|c|}{$\mathrm{g}$ ai ha ${ }^{-1}$} & \\
\hline Bispyribac-sodium & $\begin{array}{l}\text { Resistant } \\
\text { Susceptible }\end{array}$ & $\begin{array}{r}>1,120 \\
16\end{array}$ & $(14-19)$ & $>69$ & $\begin{array}{r}142 \\
6.8\end{array}$ & $\begin{array}{c}(112-171) \\
(5.2-8.5)\end{array}$ & 21 \\
\hline Halosulfuron & $\begin{array}{l}\text { Resistant } \\
\text { Susceptible }\end{array}$ & $\begin{array}{r}>1,680 \\
18\end{array}$ & $(11-29)$ & $>95$ & $\begin{array}{r}116 \\
1.6\end{array}$ & $\begin{array}{l}(99-132) \\
(1.5-1.8)\end{array}$ & 71 \\
\hline Imazamox & $\begin{array}{l}\text { Resistant } \\
\text { Susceptible }\end{array}$ & $\begin{array}{r}>1,120 \\
73\end{array}$ & $(64-83)$ & $>15$ & $\begin{array}{r}261 \\
21\end{array}$ & $\begin{array}{c}(234-288) \\
(19-23)\end{array}$ & 12 \\
\hline Penoxsulam & $\begin{array}{l}\text { Resistant } \\
\text { Susceptible }\end{array}$ & $\begin{array}{r}563 \\
21\end{array}$ & $\begin{array}{c}(226-5,436) \\
(17-26)\end{array}$ & $>26$ & $\begin{array}{l}59 \\
2.7\end{array}$ & $\begin{array}{c}(53-64) \\
(2.3-3.2)\end{array}$ & 22 \\
\hline
\end{tabular}

a Abbreviations: $\mathrm{LD}_{50}$, amount of herbicide required to kill $50 \%$ of plants and $\mathrm{GR}_{50}$, amount of herbicide needed to reduce plant growth by $50 \%$.

${ }^{\mathrm{b}}$ Values in parentheses represent $95 \%$ confidence intervals.

${ }^{\mathrm{c}}$ Bispyribac-sodium treatments contained a nonionic spray adjuvant and deposition aid at 2.5\% v/v; imazamox and halosulfuron treatments contained nonionic surfactant at $0.25 \% \mathrm{v} / \mathrm{v}$; and penoxsulam contained crop oil concentrate at $1 \% \mathrm{v} / \mathrm{v}$. 
Table 4. Nonlinear regression equation parameters, and herbicide concentrations required for $50 \%$ inhibition of acetolactate synthase (ALS) enzyme in vitro and corresponding resistance index values of ALS-inhibiting herbicide-resistant and -susceptible smallflower umbrella sedge biotypes. ${ }^{\text {a }}$

\begin{tabular}{|c|c|c|c|c|c|c|c|}
\hline \multirow[b]{2}{*}{ Biotype } & \multirow[b]{2}{*}{ Herbicide } & \multicolumn{4}{|c|}{ Regression equation parameters ${ }^{b}$} & \multirow[b]{2}{*}{$\mathrm{I}_{50}$} & \multirow[b]{2}{*}{$\mathrm{RI}^{\mathrm{c}}$} \\
\hline & & $y 0$ & $a$ & $b$ & $R^{2}$ & & \\
\hline & & & & & & $\mu \mathrm{M}$ & \\
\hline Resistant & Halosulfuron & 29.5 & 70.5 & 8.3 & 0.92 & 0.660 & 12.5 \\
\hline Susceptible & Halosulfuron & 2.5 & 97.5 & 20.5 & 0.99 & 0.053 & \\
\hline Resistant & Imazamox (acid) & 6.8 & 70.9 & 0.02 & 0.87 & 40.5 & 942 \\
\hline Susceptible & Imazamox (acid) & 15.5 & 84.5 & 18.3 & 0.98 & 0.043 & \\
\hline
\end{tabular}

${ }^{\text {a }}$ Abbreviations: ALS, acetolactate synthase; $\mathrm{I}_{50}$, herbicide concentration required to cause a $50 \%$ inhibition of ALS enzyme activity in vitro; RI, resistance index.

${ }^{\mathrm{b}}$ Regression equation parameters were generated by fitting a nonlinear regression equation of the form $y=y 0+a^{-b x}$ to response of ALS enzyme to herbicide concentration. Details are provided in the text.

${ }^{\mathrm{c}}$ Values represent ratios of $\mathrm{I}_{50}$ values of resistant to susceptible biotypes within each herbicide.

ALS Gene Sequencing. Two contigs were identified as ALS transcripts from each of the resistant and susceptible transcriptome assemblies. ALS genes were fully assembled in the four contigs, and the complete coding sequences were identified by comparing with Schoenoplectiella wallichii ALS mRNA sequence (NCBI accession AB492863). The two contigs from the same assembly have identical coding sequences with each other. The complete coding region of the ALS gene is $1,926 \mathrm{bp}$ in smallflower umbrella sedge. Comparison of coding regions revealed four single nucleotide polymorphisms (SNPs) and a sequence identity of $99.79 \%$ between the two biotypes. The four SNPs were shown in the supplementary file 'SUS_ORF_alignment.phy'. Of the four SNPs, two were silent and two were missense. The two missense SNPs resulted in an amino acid substitution of $\mathrm{Ile}_{59}$-to-Phe and Pro ${ }_{168}$-to-His in susceptible to resistant biotypes, respectively. Mapping reads to the ALS coding sequences did not reveal any heterozygous SNPs, insertion or deletion within each biotype. For convention in discussing herbicide resistance, amino acid numbering in the ALS gene is commonly based on Arabidopsis thaliana. In aligning the amino acid sequences of resistant and susceptible smallflower umbrella sedge, $\mathrm{Pro}_{168}$ aligns to $\mathrm{Pro}_{197}$ in A. thaliana (Figure 1). $\mathrm{Pro}_{197}$-to-His at this position has been reported to confer different resistance levels to IMI, SU, and/or TP in prickly lettuce (Lactuca serriola L.), wild radish (Raphanus raphanistrum L.), corn poppy (Papaver rhoeas L.), rock bulrush [Schoenoplectus juncoides (ROXB.) Palla], ricefield bulrush [Schoenoplectus mucronatus (L.) Palla], and shepherd'spurse [Capsella bursa-pastoris (L.) Medik] (Tranel et

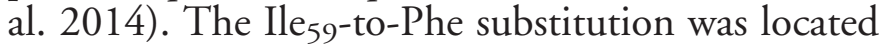
within the chloroplast transit peptide of the ALS gene according to the prediction by ChloroP 1.1 Server, indicating a rare possibility that this substitution contributed to the ALS-inhibitor resistance. Despite that moderate levels of resistance to imidazolinone herbicides were conferred by $\mathrm{Pro}_{197^{-}}$ to-His substitution in previous reports, it may cause high level of resistance in smallflower umbrella sedge. This is the first amino acid substitution at the

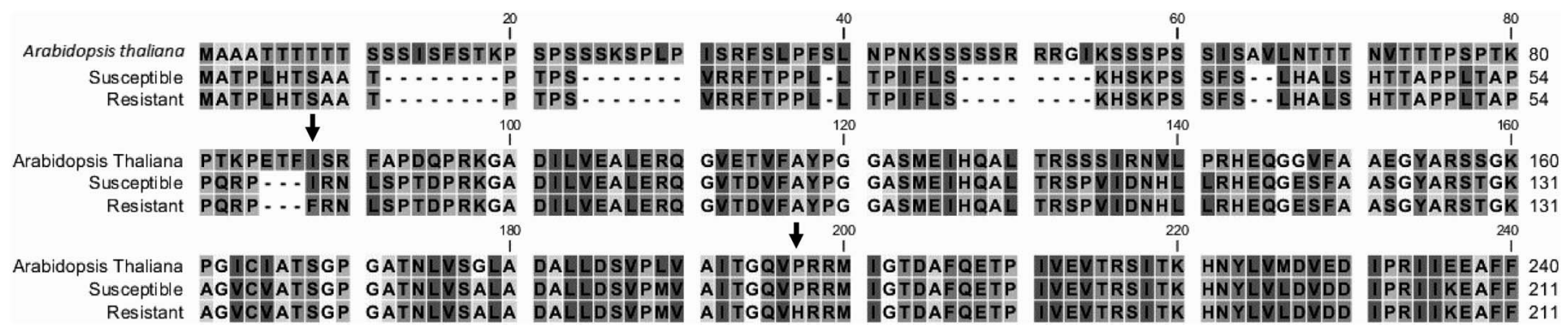

Figure 1. The alignment of the acetolactate synthase (ALS) amino acid sequences of Arabidopsis thaliana, susceptible and resistant smallflower umbrella sedge biotypes. The black arrows indicate the two single-nucleotide polymorphisms between the susceptible and resistant smallflower umbrella sedge biotypes. The alignment showed the Pro-to-His substitution in the resistant biotype occurred at the Pro $_{197}$ codon of the $A$. thaliana ALS gene.

566 - Weed Science 63, July-September 2015 
known site of mutations found in this species worldwide. Additionally, variations in the amino acid sequence of smallflower umbrella sedge could alter the impact of such an amino acid substitution. Considering the recorded correlation of $\mathrm{Pro}_{197}$-toHis substitution with the ALS-inhibitor resistance, it can be concluded that this substitution confers resistance to the resistant biotype.

In summary, an amino acid substitution in the ALS gene of the resistant biotype from Arkansas, at least in part, resulted in resistance to halosulfuron and imazamox. According to Tranel et al. (2014), $>10$-fold resistance is considered as a high level of resistance indicating target site mutation(s). The ALS isozymes with different expression level can be one of the reasons for less-than-expected halosulfuron $\mathrm{I}_{50}$ value of the resistant biotype. Future research should be directed at determining whether elevated metabolism, e.g., enhanced herbicide metabolism by cytochrome $\mathrm{P} 450$ or other potential mechanisms, contribute to the lack of control with penoxsulam and bispyribac-sodium. Non-targetsite-based resistance owing to enhanced herbicide metabolism is also widely documented as a cause for the evolution of ALS-resistant weed species (Riar et al. 2013; Yasuor et al. 2009; reviewed in Yuan et al. 2007). Furthermore, given the importance of the competitive impact of sedges on rice production, herbicides that can control ALS-resistant smallflower umbrella sedge (i.e., bentazon and propanil) should be used prudently within an integrated weed management system.

\section{Acknowledgments}

The authors are thankful to the Arkansas Rice Research and Promotion Board for funding of this research.

\section{Literature Cited}

Baltazar AM, Smith, Jr. RJ (1994) Propanil-resistant barnyardgrass (Echinochloa crus-galli) control in rice (Oryza sativa). Weed Sci 8:576-581

Bräutigam A, Gowik U (2010) What can next generation sequencing do for you? Next generation sequencing as a valuable tool in plant research. Plant Biol 12:831-841

Busi R, Vidotto F, Fischer AJ, Osuna MD, De Prado R, Ferrero A (2006) Patterns of resistance to ALS herbicides in smallflower umbrella sedge (Cyperus difformis) and ricefield bulrush (Schoenoplectus mucronatus). Weed Technol 20:1004-1014

Galon L, Panozzo LE, Noldin JA, Concenço G, Tarouco CP, Ferreira EA, Agostinetto D, Silva AA, Ferreira FA (2008) Herbicide resistance of Cyperus difformis to ALS-inhibitors in paddy rice of Santa Catarina. Planta Daninha 26:419-427
Graham RJ, Pratley JE, Slater PD, Baines PR (1996) Herbicide resistant aquatic weeds, a problem in New South Wales rice crops. Pp 156-158 in Sheperd RCH, ed. Proceedings of the 11th Australian Weeds Conference, Melbourne, Australia. Parkville, Victoria, Australia: Weed Science Society of Victoria

Haas BJ, et al. 2013. De novo transcript sequence reconstruction from RNA-seq using the Trinity platform for reference generation and analysis. Nature Prot 8:1494-1512

Heap I (2014) The International Survey of Herbicide Resistant Weeds. http://www.weedscience.com. Accessed September 24, 2014

Kuk YI, Kim KH, Kwon OD, Lee DJ, Burgos NR, Jung S, Guh JO (2004) Cross-resistance pattern and alternative herbicides for Cyperus difformis resistant to sulfonylurea herbicides in Korea. Pest Manag Sci 60:85-94

Lovelace ML (2003) Implications of quinclorac use in Arkansas: impacts of quinclorac drift on tomato physiology and development of quinclorac resistance in barnyardgrass. Ph.D dissertation. Fayetteville, AR: University of Arkansas. Pp 7071

McWilliam H, Li W, Uludag M, Squizzato S, Park YM, Buso N, Cowley AP, Lopez R (2013) Analysis tools web services from the EMBL-EBI. Nucl Acids Res 41: W597-W600

Merotto A, Jr, Jasieniuk M, Osuna MD, Vidotto F, Ferrero A, Fischer AJ (2009) Cross-resistance to herbicides of five ALSinhibiting groups and sequencing of the ALS gene in Cyperus difformis L. J Agric Food Chem 57:1389-1398

Nandula VK, Messersmith CG (2000) Mechanism of wild oat (Avena fatua L.) resistance to imazamethabenz-methyl. Pestic Biochem Physiol 68:148-155

Norsworthy JK, Bond J, Scott RC (2013a) Weed management practices and needs in Arkansas and Mississippi rice. Weed Technol 27:623-630

Norsworthy JK, Riar DS, Scott RC (2013b) Control options for ALS-resistant smallflower umbrella sedge in Arkansas rice. Pp 222-226 in Norman RJ, Meullenet JF, Moldenhauer KAK, eds. B.R. Wells Arkansas Rice Research Studies. Fayetteville, AR: University of Arkansas Agricultural Experiment Station Research series 617

Norsworthy JK, Scott R, Smith K, Still J, Estorninos LE, Jr, Bangarwa S (2009) Confirmation and management of clomazone-resistant barnyardgrass in rice. Proc South Weed Sci Soc 62: 210 [Abstract]

Osuna MD, Vidotto F, Fischer AJ, Bayer DE, De Prado R, Ferrero A (2002) Cross resistance to bispyribac-sodium and bensulfuron-methyl in Echinochloa phyllopogon and Cyperus difformis. Pestic Biochem Physiol 73:9-17

Pedroso RM, Boddy LG, Fischer A (2013) Propanil resistance in smallflower umbrella sedge (Cyperus difformis L.): a new challenge to rice growers in California. http://wssaabstracts. com/public/17/acrebstract-11.html. Accessed February 11, 2014

Powles SB, Yu Q (2010) Evolution in action: plants resistant to herbicides. Annu Rev Plant Biol 61:317-347

Riar DS, Norsworthy JK, Bond JA, Bararpour MT, Wilson MJ, Scott RC (2012) Resistance of Echinochloa crus-galli populations to acetolactate synthase-inhibiting herbicides. Int J Agron 2012:893-953

Riar DS, Norsworthy JK, Srivastava V, Nandula V, Bond JA, Scott RC (2013) Physiological and molecular basis of acetolactate synthase-inhibiting herbicide resistance in barnyardgrass (Echinochloa crus-galli). J Agric Food Chem 61:278-289

Tehranchian et al.: ALS-resistant smallflower umbrella sedge • 567 
Ruiz-Santaella JP, Bakkaliu Y, Osuna MD, De Prado R (2004) Evaluation of resistance in Cyperus difformis populations to ALS inhibiting herbicides. Comm Agri Appl Biol Sci 69:91-96

Scott RC, Boyd JW, Smith KL, Selden G, Norsworthy JK (2013) Recommended Chemicals for Weed and Brush Control. University of Arkansas Division of Agriculture, Cooperative Extension Service, Miscellaneous Publication 44. $36 \mathrm{p}$

Siminszky B (2006) Plant cytochrome P450-mediated herbicide metabolism. Phytochem Rev 5:445-458

Tranel PJ, Wright TR (2002) Resistance of weeds to ALSinhibiting herbicides: what have we learned? Weed Sci 50:700-712

Tranel PJ, Wright TR, Heap IM (2014) Mutations in herbicideresistant weeds to ALS inhibitors. http://weedscience.com. Accessed September 24, 2014

Vidotto F, Busi R, Ferrero A (2003) Schoenoplectus mucronatus (L.) Palla and Cyperus difformis L. accessions resistant to ALS- inhibitors in Italian rice fields. In Proceedings of the Third International Temperate Rice Conference. Unpaginated CD Wilson MJ, Norsworthy JK, Johnson DB, McCallister EK, Devore JD, Griffith GM, Bangarwa SK, Scott RC, Smith KL (2009) Herbicide programs for controlling ALS-resistant barnyardgrass in Arkansas rice. Pages 153-157 in Norman RJ, Meullenet JF, Moldenhauer KAK, eds. B.R. Wells Arkansas Rice Research Studies. Fayetteville, AR: University of Arkansas Agricultural Experiment Station Research series 581.

Yasuor H, Osuna MD, Ortiz A, Saldaín NE, Eckert JW, Fischer AJ (2009) Mechanism of resistance to penoxsulam in late watergrass [Echinochloa phyllopogon (Stapf) Koss.]. Agric Food Chem 57:3653-3660

Yuan JS, Tranel PJ, Stewart CN, Jr (2007) Non-target-site herbicide resistance: a family business. Trends Plant Sci 12:6-13

Received October 2, 2014, and approved January 26, 2015. 